\title{
THE WURAWINA SUPERGROUP, LATE CAMBRIAN TO EARLY DEVONIAN, TASMANIA
}

\author{
by M.R. Banks and E. Williams
}

BANKS, M.R.\& WILLIAMS, E., 1986 (21:ix): The Wurawina Supergroup, Late Cambrian to Early Devonian, Tasmania. Pap. Proc. R. Soc. Tasm. 120: 95-96. https://doi.org/10.26749/rstpp.120.95 ISSN 0080-4703. University of Tasmania, Hobart, Tasmania and Department of Mines, Rosny Park, Tasmania, Australia.

The term "Wurawina Supergroup" is proposed for the conformable sequence in western Tasmania consisting of the Denison Group, the Gord on Group and the Eld on Group or the Tiger Range Group and their correlates. The Supergroup rests on early Late Cambrian or older rocks and is folded, and then intruded by Late Devonian and Early Carboniferous granites. It is Late Cambrian at the base and Early Devonian at the top.

Key Words: Early Palaeozoic, Tasmania, Supergroup.

\section{INTRODUCTION}

Phrases such as "the rocks of the Junee Group and the Eldon and Tiger Range Groups ..." and "The Late Cambrian to Early Devonian conformable succession of sedimentary rocks ..." occur quite frequently in geological literature on western Tasmania, especially in regional review papers. A short term to replace such circumlocutions seems likely to be useful.

\section{BACKGROUND}

The Junee Group of Hills and Carey (1949), consists in the main of correlates of the Junee Series of Lewis (1940) and rests, usually with angular unconformity, on early Late Cambrian or older rocks. Corbett and Banks (1975) treated the formations in it as belonging to two subgroups, the Denison Subgroup below and the Gordon Subgroup above. Subsequently Burrett el al. (1984) have raised the Subgroups to Group status.

The Denison Group defined in the Denison Range of south-central Tasmania, is a sequence of conformable beds of clastic rocks of Late Cambrian and Early Ordovician age (Corbett 1975). Correlates of the Denison Group contain some disconformities in the lower part and angular unconformities (e.g. Haulage) occur within the lower part of the group (Adams et al. 1985). The Denison Group grades up into the Gordon Group.

The Gordon Group defined in the Florentine Valley of south-central Tasmania (Corbett \& Banks 1974), and its correlates consist of a conformable marine succession of predominantly carbonate rocks with minor siltstone and fine sandstone ranging in age from Early Ordovician (base) to Early Silurian (top) (Banks \& Burrett 1980). The group when first used as a subgroup by Corbett $\&$
Banks (1974) excluded the Westfield Beds and this usage was applied to the Group by Burrett et al. (1984). However Corbett \& Banks (1975) included the Westfield Beds in the Subgroup and this practice is followed here. The unit, the Westfield Beds, has since been included as part of the laternamed Arndell Sandstone (Baillie 1979) which was also included in the Gordon Group because the base of the overlying Tiger Range Group (a correlate of the Eldon Group in western Tasmania) is much more readily recognizable in field mapping than the top of the limestone below the Arndell Sandstone equivalents.

In western Tasmania correlates of the Gordon Group are overlain concordantly, but in places with disconformity, by the Eldon Group. In southcentral Tasmania it is overlain gradationally by the Tiger Range Group (Baillie 1979). These groups range in age from Early Silurian (base) to Early Devonian (top) (Talent \& Banks 1967, Baillie 1979).

The Denison, Gordon and Tiger Range Groups, and their correlates were folded together in Early to Middle Devonian time, overlain unconformably at Eugenana in northern Tasmania by the late Middle Devonian Eugenana Beds (Balme 1960) and intruded in several places by granitic rocks with $\mathrm{K}-\mathrm{Ar}$ ages ranging from 332 to 367 m.y. (Collins \& Williams 1986). The folded intruded rocks are overlain on a erosional surface by Late Carboniferous (or Early Permian, possibly, in places) sedimentary rocks of the Parmeener Supergroup.

\section{DEFINITION}

The term "Wurawina Supergroup" is proposed for a unit in western Tasmanian comprising 
the Denison Group below the Gordon Group and the Eldon Group or Tiger Range Group above, bounded basally by an unconformity, and overlain with angular unconformity by the Parmeener Supergroup of Late Carboniferous to Triassic age. The Supergroup is Late Cambrian at the base and Early Devonian at the top.

\section{DERIVATION OF NAME}

Wurawina is the name of a lake in the Denison Range in south-central Tasmania. Its geographic coordinates are $146^{\circ} 16^{\prime} 43^{\prime \prime} \mathrm{E}, 42^{\circ} 32^{\prime} 24^{\prime \prime} \mathrm{S}$ (Australian Map Grid Zone 55 DN408901). It lies in an area dominated by units of the Supergroup.

\section{DISCUSSION}

It is appropriate to apply the term Supergroup to this unit as it consists of an essentially conformable succession of sedimentary rocks, some formations within which have already been aggregated into Groups.

\section{ACKNOWLEDGEMENTS}

The authors glady acknowledge the helpful discussions held with Dr Clive Burrett, University of Tasmania. E. Williams published with permission of the Director of Mines, Tasmania.

\section{REFERENCES}

ADAMS, C.J., BLACK. C.P., CORBETT, K.D. \& GREEN, G.R., 1985: Reconnaissance isotopic studies bearing on the tectonothermal history of Early Palaeozoic and Late Proterozoic sequences in western Tasmania. Aust. J. Earth Sci. 32: $7-36$.
BAILLIE, P., 1979: Stratigraphic relationships of Late Ordovician to Early Devonian rocks in the Huntley Quadrangle, south-western Tasmania. Pap. Proc. R. Soc. Tasm. 113: 5-13.

BALME, B.E., 1960: Palynology of a sediment from Halletts Quarry, Melrose, Tasmania. Palyn Rept Depi Geol. Univ. W.A. 62.

BANKS, M.R. \& BURRETT, C.F., 1980: A preliminary Ordovician biostratigraphy of Tasmania. J. geol. Soc. Aust. 26: 363-376.

BURRETT, C.F., STAIT, B., SHAR PLES, C. \& LAURIE, J., 1984: Middle-Upper Ordovician shallow platform to deep basin transect, southern Tasmania, Australia. In BRUTON, D.L. (Ed.) ASPECTS OF THE ORDOVICIAN SYSTEM: 149-157. Univ. of Oslo, Universitsforlaget.

COLLINS, P.L.F.\& WILLIAMS, E., 1986: Metallogeny and tectonic development of the Tasman Fold Belt System in Tasmania. Ore Geology, in press.

CORBETT, K.D., 1975: The Late Cambrian to Early Ordovician sequence on the Denison Range, southwest Tasmania. Pap. Proc. R. Soc. Tasm. 109: $111-120$

CORBETT, K.D. \& BANKS, M.R., 1974: Ordovician stratigraphy of the Florentine Synclinorium, southwest Tasmania. Pap. Proc. R. Soc. Tasm 107: 207-238.

CORBETT, K.D. \& BANKS, M.R., 1975: Revised terminology of the Late Cambrian-Early Ordovician sequence of the Florentine-Denison Range area and the significance of the Junee Group. Pap. Proc, R. Soc. Tasm. 109: 121-126.

TALENT, J.A. \& BANKS, M.R, 1967: Devonian of Victoria and Tasmania. In OSWALD, D.H. (Ed.): INTERNATIONAL SYMPOSIUM ON THE DEVONIAN SYSTEM 2: 147-163. Calgary, Alberta.

(accepted Mar. 10, 1986) 